\title{
Research on the Development and Countermeasure of Industrial Clusters in Heilongjiang under the Background of Mongolia and Russia Economic Corridor
}

\author{
Yang Shuang, Sun Demei \\ Harbin Engineering University \\ Harbin, China \\ 457972803@qq.com
}

\begin{abstract}
In the case of "Mongolia and Russia economic corridor", the cooperation among nations is becoming more and more frequent, as the North bridgehead only starting from the whole mining industrial clusters play a specific regional competitive advantage can Heilongjiang Province promote economic prosperity. This paper uses the method of system dynamics to study the four factors of Heilongjiang Industrial Cluster: the influence of capital, technology, talent and market in the future. The research shows that only increase capital investment, achieve interoperability of infrastructure, can the government let the resources, talent, technology and other elements of the rapid flow, expand the economy formation of Mongolia and Russia and promote the development of regional and external resources and market.
\end{abstract}

Keywords-industrial clusters; system dynamics; Mongolia and Russia economic corridor ${ }^{1}$

\section{INTRODUCTION}

After 18th CPC National Congress, the Party Central Committee and the State Council took a rebalancing of the global economy and new pattern of adjustment, from the national conditions, put forward the construction of the new strategy "The Belt and Road "in china. Heilongjiang province actively plan to integrate into the "The Belt and Road" national development strategy and put forward the construction of the economic corridor of Mongolia and Russia - Heilongjiang Sea Silk Road Economic Belt from the angle of regional development. This is a communication and the establishment of Russia, Mongolia and China's new development path of an important corridor, Not only can promote the three national quality inspection of energy and resources cooperation and development, accelerate the Mongolia and Russia three party personnel, goods fast flow, to achieve the development of an open border and expand economic scale, the formation of Mongolia and Russia to

Fund Project: Heilongiiang Province philosophy social science project "Mongolia and Russia economic corridor under the background of" Heilongjiang Economic Zone Industrial Cluster Development Countermeasure research" KY10900160002 promote the development of regional resources inside and outside and the market is also important. Industrial clusters dig out the competitive advantages of specific regions from the whole, and focus on the interaction of enterprises, related organizations, government and non-governmental organizations in a certain region. Therefore, the industrial cluster has great significance for implementing the spirit of the CPC Central Committee, implementing "The Belt and Road" strategy, establishing Mongolia and Russia economic corridor, driving the rapid development of health in Heilongjiang Province and forming a new economic growth point.

\section{LITERATURE REVIEW}

Xiaohua Sun put forward industrial agglomeration effect promotion countermeasure with talent, market, technology, capital as the core, which is based on the basic analysis framework of the industrial agglomeration effect summarized in the system dynamics ${ }^{[1]}$. Naiwen Li used system dynamics method to analyze the interaction between industrial cluster and talent cluster, which provides the basis for the development of industrial cluster ${ }^{[2]}$. Xiangmin Cui reached on the evolution of industrial clusters and focus on the role of government in the industrial cluster ${ }^{[3]}$. Zhihe Zhang took Optics Valley in China as an example to study the formation mechanism of strategic emerging industry clusters and gave the conclusion that independent innovation in the emerging industrial clusters is important after analysis ${ }^{[4]}$. Jun Wang proposed the concept of the derived cluster based on the analysis of the formation conditions and process of the industrial cluster in the West Bank of the Pearl River Delta ${ }^{[5]}$. Lue Lin applied the industrial agglomeration effect to the development of inland bonded port area and calculated the four aspects of talents, technology, capital and logistics of inland bonded port area with the help of system dynamics method in the new "The Belt and Road" situation ${ }^{[6]}$.

The existing literature in the study of industrial clusters is limited to the status quo analysis and put forward to improve the views of the level. There is no literature on "Mongolia and Russia economic corridor" in Heilongjiang Province under the background of the development of industrial cluster analysis. 


\section{CONSTRUCTION OF SYSTEM DyNAMICS MODEL OF INDUSTRIAL Cluster IN HEILONGJIANG PROVINCE}

Talent, technology, capital and market play a decisive role in the formation of industrial clusters. In the process of development of industrial clusters in Heilongjiang Province, there are restriction factors like insufficient funds, lack of government and policy support, weak innovation ability of the cluster, the decline in market share.

Heilongjiang province has formed four leading industrial clusters, namely, the equipment manufacturing industry cluster, the petrochemical industry cluster, the energy industry cluster and the food industry cluster. These four leading industrial clusters have an important support and leading role in the economic development of other industries and even the whole Heilongjiang province. Therefore, this paper analyze and forecast to provide decision-making for the overall development of the industrial cluster in Heilongjiang by using the four leading industrial clusters to establish a system dynamics model for the study.

\section{A. Construction of System Flow Diagram}

Industrial cluster related diagrams are shown in Fig. 1 and Fig. 2.

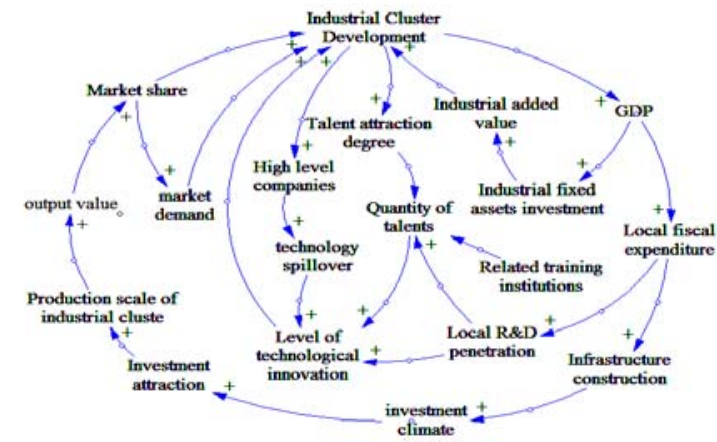

Fig.1. Causal loop

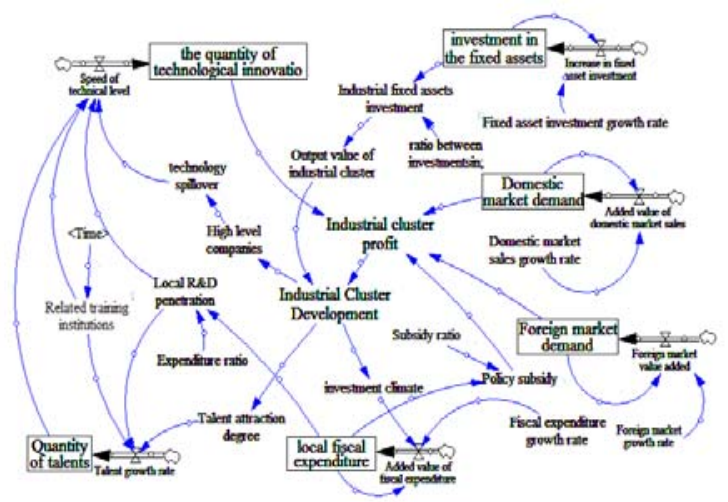

Fig.2. System structure flow chart

This paper uses the PLE Vensim system dynamics software to simulate the simulation. The simulation range is from 2010 to 2030, the simulation step is 1 year and the main data in the model is from the statistical yearbook of Heilongjiang province. The main system dynamics equations are listed in TABLE I-IV below.

\section{TABLE I. AUXILIARY VARIABLE EQUATION}

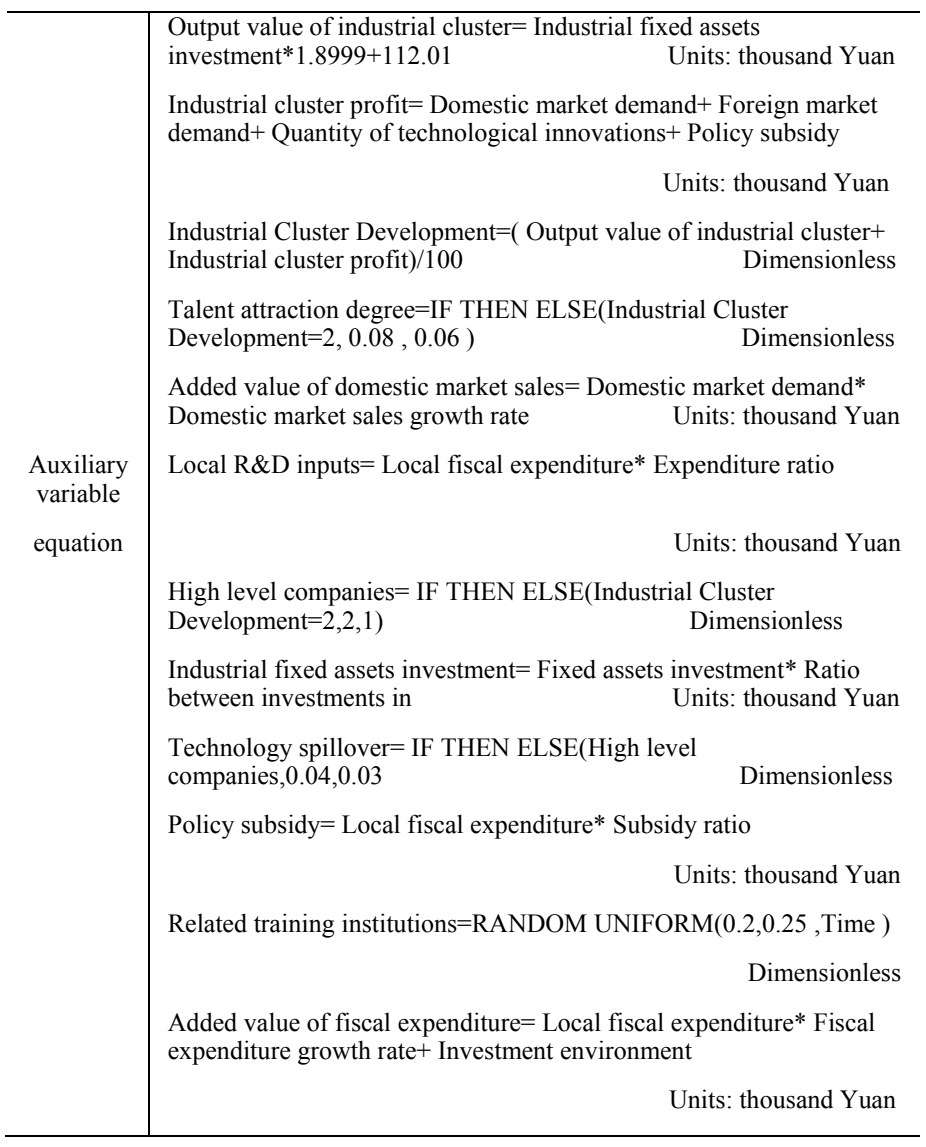

TABLE II. RATE VARIABLE EQUATION

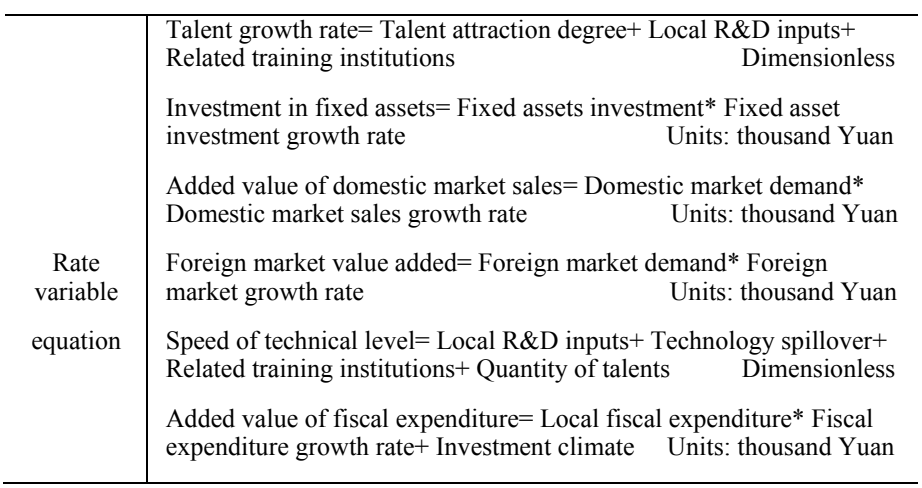

TABLE III

\section{CONSTANT}

\begin{tabular}{l|l}
\hline \multirow{3}{*}{ Constant } & $\begin{array}{l}\text { Fixed asset investment growth rate }=0.1806 \\
\text { Domestic market sales growth rate }=0.1358 \\
\text { Foreign market growth rate }=0.025 \\
\text { Ratio between investments in }=0.6 \\
\text { Expenditure ratio }=0.02 \\
\text { Foreign market value added }=0.19 \\
\text { Subsidy ratio }=0.015\end{array}$ \\
\hline
\end{tabular}


TABLE IV.

LEVEL VARIABLE EQUATION

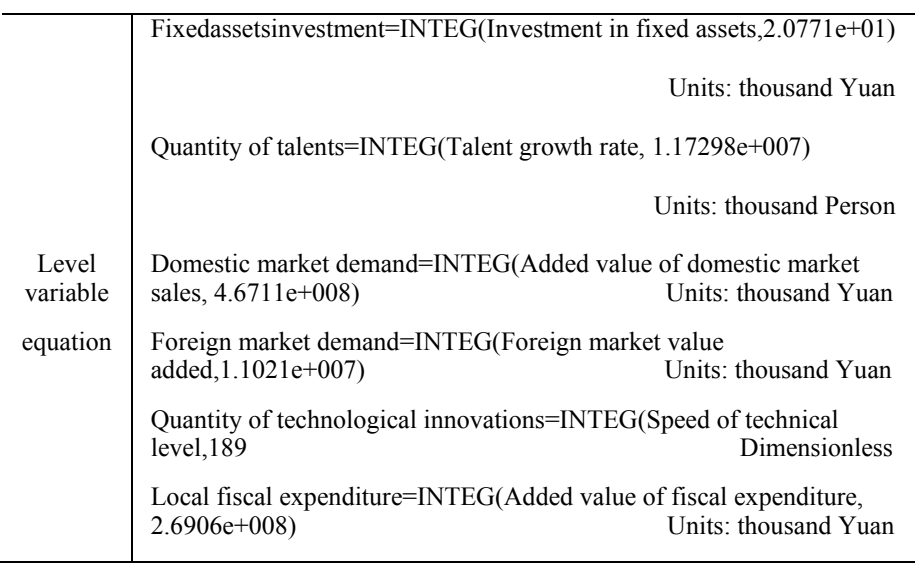

\section{B. Validity test of system dynamics model}

TABLE V. THE VALIDITY TEST OF THE MODEL IN 2011

\begin{tabular}{cccc}
\hline Index name & $\begin{array}{c}\text { actual } \\
\text { value(Million) }\end{array}$ & $\begin{array}{c}\text { Simulation } \\
\text { value(Million) }\end{array}$ & Error value (\%) \\
\hline $\begin{array}{c}\text { Fixed assets } \\
\text { investment }\end{array}$ & 21777000 & 24531000 & 12.6 \\
$\begin{array}{c}\text { Foreign market } \\
\text { demand }\end{array}$ & 11413000 & 10922000 & -4.3 \\
$\begin{array}{c}\text { Quantity of } \\
\text { talents }\end{array}$ & 1.476 & 1.352 & -7.7 \\
\hline
\end{tabular}

TABLE VI.

THE VALIDITY TEST OF THE MODEL IN 2012

\begin{tabular}{cccc}
\hline Index name & $\begin{array}{c}\text { actual } \\
\text { value(Million) }\end{array}$ & $\begin{array}{c}\text { Simulation } \\
\text { value(Million) }\end{array}$ & Error value (\%) \\
\hline $\begin{array}{c}\text { Fixed assets } \\
\text { investment }\end{array}$ & 300940 & 289710 & -3.7 \\
$\begin{array}{c}\text { Foreign market } \\
\text { demand }\end{array}$ & 106560 & 108230 & 1.6 \\
$\begin{array}{c}\text { Quantity of } \\
\text { talents }\end{array}$ & 1.342 & 1.215 & -9.5 \\
\hline
\end{tabular}

TABLE VII.

THE VALIDITY TEST OF THE MODEL IN 2013

\begin{tabular}{cccc}
\hline Index name & $\begin{array}{c}\text { actual } \\
\text { value(Million) }\end{array}$ & $\begin{array}{c}\text { Simulation } \\
\text { value(Million) }\end{array}$ & Error value (\%) \\
\hline $\begin{array}{c}\text { Fixed assets } \\
\text { investment }\end{array}$ & 334870 & 342140 & 2.2 \\
$\begin{array}{c}\text { Foreign market } \\
\text { demand }\end{array}$ & 100520 & 107260 & 6.7 \\
$\begin{array}{c}\text { Quantity of } \\
\text { talents }\end{array}$ & 1.197 & 1.096 & -8.4 \\
\hline
\end{tabular}

a. Ratio, ratio, growth rate and other variables, all take the average value of 2010-2014 years

From the TABLE V-VII can be seen from 2011 to 2013 and the real data simulation error statistics ranged $-10 \% 10 \%$, indicating that the deviation between the model operation results and the actual data meet modeling accuracy requirements, that is the result of simulation is reliable. It also shows that the system dynamics model of the four major industrial clusters in Heilongjiang province can represent the actual system effectively and the model is suitable for simulation and policy analysis.

\section{RESULTS AND ANALYSIS}

\section{A. Sensitivity Analysis of Fixed Asset Investment Growth Rate}

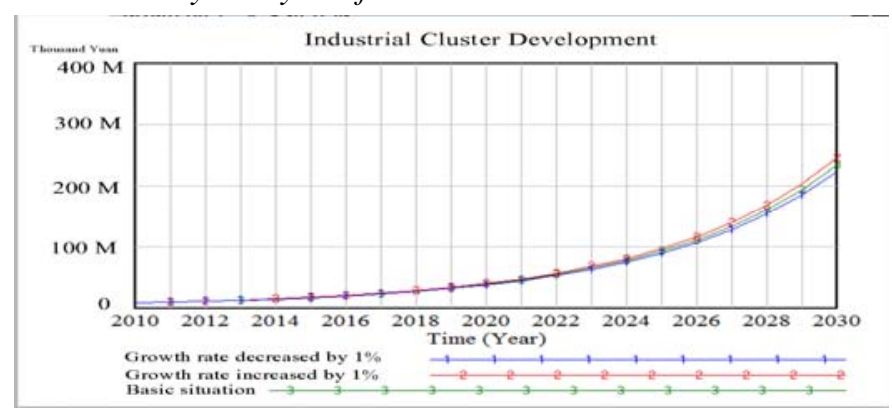

Fig.3. Industrial Cluster Development

It can be seen from the Fig. 3, in the case of other conditions unchanged, the development of the four leading industrial clusters and the growth rate of fixed assets investment is in positive relationship. In the earlier years, the growth of investment in fixed assets has little impact on the four leading industry cluster development. This is determined by the long-term nature and time delay of fixed assets investment, besides, the construction of the infrastructure also needs a certain period of time. But from the late results, to 2024, when the fixed asset investment rate increased by $1 \%$, the development level of the four leading industrial clusters is significantly higher than two situations. It shows that increasing the rate of investment in fixed assets has an important influence on the development of industrial clusters.

\section{B. Local R\&D Expenditure Ratio Sensitivity Analysis}

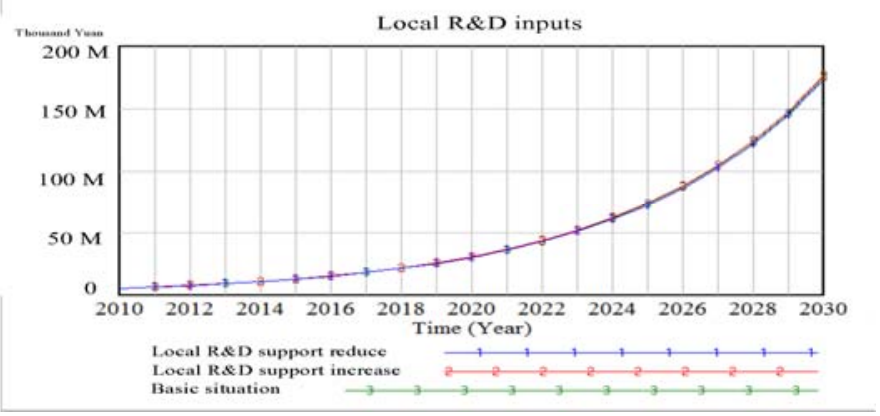

Fig.4. Local R\&D inputs

According to the Fig. 4, the previous 10 years in the simulation, the local $R \& D$ expenditure ratio increased or decreased $1 \%$ has little impact on the four leading industry cluster development. Since 2020, changes in the proportion of local R\&D spending on the development of the four leading industrial clusters gradually increased. Therefore, we must improve the proportion of local $R \& D$ funds and construct technology research and development innovation platform for industry cluster to promote the development of industrial clusters in Heilongjiang Province. 


\section{Sensitivity Analysis of the Proportion of Policy Subsidy}

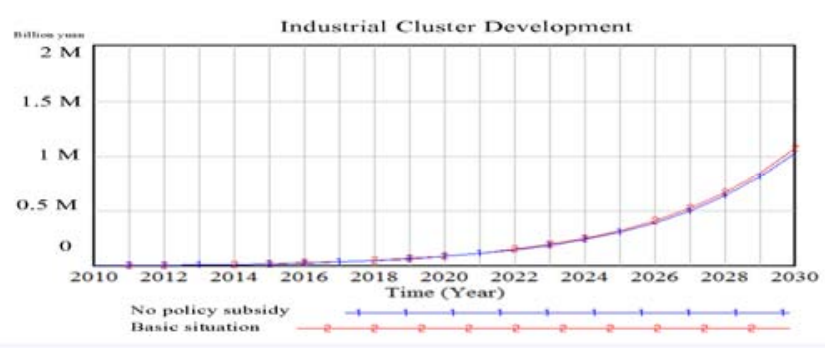

Fig.5. Industrial Cluster Development

According to the Fig. 5 show that the tax subsidies for the equipment manufacturing industry cluster development has little effect. At the beginning of the construction and development of industrial clusters in Heilongjiang Province, the government attract more enterprises to enter the industrial park by tax subsidies and incentives. It is conducive to the growth of the industrial scale, form industrial advantages and promote the development of related industries. With the development of the industry cluster, the influence of the tax subsidy to the development of the industrial cluster is gradually becoming smaller.

\section{Sensitivity Analysis of Domestic Market Demand}

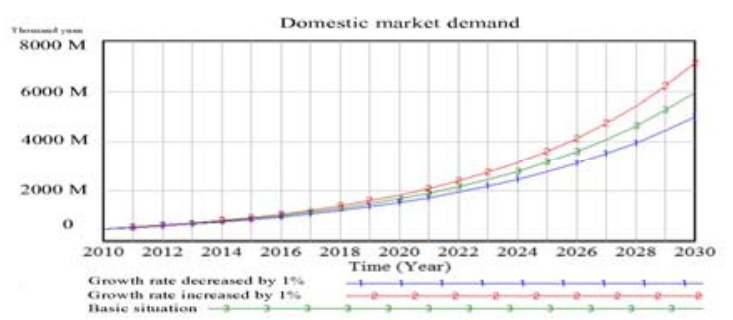

Fig.6. Domestic market demand

It can be seen from the Fig. 6, ceteris paribus, the domestic market demand has a great impact on the development of industrial clusters in Heilongjiang province, which shows that the product market of Heilongjiang industrial cluster is mainly in the domestic market. At this stage, with the industrial structure in China optimize and upgrade continuously, we should adhere to stabilized the first industry strengthen the second industry and expand the third industry. Under such a background, the production of industrial clusters in Heilongjiang province must be closely combined with the market demand to give full play to the advantages and improve the technical level of products.

\section{CONCLUSION}

\section{A. Fixed Assets Investment}

We should ensure the reasonable growth of fixed asset investment, broaden financing channels and increase investment efforts. The simulation results show that the funds from 207 billion 710 million in 2010 to 57149 in 2029 , such a huge amount of capital demand must be guaranteed, otherwise, the development of industrial clusters in Heilongjiang province will be difficult. Thus increasing the introduction of domestic investment capital is imminent.

\section{B. Market Demand}

We should expand market demand to accelerate the construction of the basic facilities of the Mongolian and Russian interconnection. To build a large international freight corridor for Russia, Northeast Asia and North America we must joint rail and water transportation as the basis. In order to facilitate the smooth flow of the rise of trade and logistics, thereby expanding the market demand for industrial clusters in Heilongjiang Province

\section{Independent Innovation}

We should improve cluster independent innovation capability and increase the Russian scientific and technological cooperation. The necessary funds for supporting technology innovation is the prerequisite and basic guarantee, so to increase the local $R \& D$ funds and corporate $R \& D$ investment funds. The government should use Russian science and technology innovation resources to enhance the innovation capability of industrial clusters in Heilongjiang province as well.

\section{ACKNOWLEDGMENT}

It took nearly two months to finish writing this paper, in the process of writing the paper has encountered numerous difficulties and obstacles. With the help of the teacher, I have overcome the difficulties. In particular, I want to thank my thesis advisor. She has made a selfless guide to me and help me to revise and improve the paper. At last, comments and suggestions are most welcome.

\section{REFERENCES}

[1] Xiaohua Sun, "System dynamics modeling and Simulation of industrial agglomeration effects," in Science and technology management, vol.319. pp.71-76, 2008. (In Chinese)

[2] Naiwen $\mathrm{Li}$ and Fangzheng $\mathrm{Li}$, "An exploration of the interaction between industrial clusters and talent clusters," in Comments on production, vol 11. pp. 14-22, 2011. (In Chinese)

[3] Xiangmin Cui and Qiang Mei, "Research on the evolution of industrial clusters based on system dynamics," in Management of science and technology, vol 210. pp. 213-215, 2010. (In Chinese)

[4] Zhihe Zhang, Haixia Huang and Zhongquan Xie, "Research on the formation mechanism of strategic emerging industrial clusters," in Studies in Science of Science, vol 177. pp. 24-28, 2010. (In Chinese)

[5] Jun Wang, "Derived cluster: A Study on the formation mechanism of industrial clusters in the West Bank of the Pearl River Delta," in Management world, vol 143. pp. 80-86, 2005. (In Chinese)

[6] Lue Lin and Xiaowei Wang, ""On The Belt and Road" inland bonded port industry cluster development -- Taking Chongqing as an example," in Economic Zone, vol 315. pp. 12-16, 2015. (In Chinese) 